\title{
ИНСТИТУЦИОНАЛИЗАЦИЯ ФОРМ ОРГАНИЗАЦИИ ОБЩЕСТВЕННОГО КОНТРОЛЯ. НА ПРИМЕРЕ СУДЕБНОЙ СИСТЕМЫ И ПРАВООХРАНИТЕЛЬНОЙ ДЕЯТЕЛЬНОСТИ
}

\begin{abstract}
Аннотация: С момента своего образования Российская Федерация прошла значительный путь от разрозненных инициатив к институциональному порядку осуществления общественного контроля в системах правосудия и правоохранительной деятельности. В отличие от стран с «естественно» сложившимися демократическими порядками, в России за короткий исторический период приходится осуществлять институционализацию общественного контроля одновременно (а не последовательно) с освоением различных практик общественного контроля. В статье проанализированы три формы организации общественного контроля. Имплантация или прямое копирование учреждений, институтов, которые конституируют современные развитые общества от рынка и до публичной политики и прав человека, в истории новой России вновь переоткрыла проблему институционализации. В российских условиях мы имеем дело не со ставшими, а со становящимися институтами, причем, во многом, процесс институционализации носит искусственный, а не естественный характер, следовательно, подходы, как к созданию, так и к анализу данной проблематики должны быть заново выработаны. В качестве методологии предложена единица анализа общественного контроля, которая представляет из себя систему из пяти элементов: (1) акторы и их взаимодействие, основанное на взаимности социального действия, действующие на принципах самоуправления, самоорганизации, самодостаточности; (2) тип цели, который связан с ограничением произвола; (3) предмет контроля-государственная деятельность; (4) способ реализации -публичная политика; (5) гражданская этика, основанная на ненасильственных методах. Эта система взята не умозрительно, а после интерпретации экспертных интервью, полученных у лидеров ведущих общественных организаций Введены представления о пяти фазах институционализации общественного контроля. Введены представления о сценариях и типах институционализации. В соответствии с предложенной методологией проанализированы три формы организачии общественного контроля: представитель общественности в квалификационных коллегиях судей, общественно-наблюдательная комиссия, гражданский контроль за деятельностью полиции.
\end{abstract}

Abstract: From the moment of its formation the Russian Federation has passed a long way from the unconnected initiatives to the institutional procedures for public control in the justice and law-enforcement systems. Unlike the states, where the democratic rule formed "naturally", Russia needs to implement institutionalization of public control in a short historic period of time, at the same time (and not consequently) with the various public control practices. The article includes analysis of three forms of public control organization. Implantation or direct copying of institutions, as constituted in the modern developed societies in the spheres ranging from the market to the public policy and human rights in the history of new Russia has reopened the institutionalization problem. In the Russian conditions we deal with the forming (and not the formed) institutions, while the institutionalization process is to a great extent artificial, and not natural. Accordingly, the approaches to the formation and analysis of these issues should be developed anew. As a methodology, the author offers a public control unit including five elements: 1) actors and their interaction based upon the reciprocal character of social act, based upon the principles of self-government, self-administration, self-sufficiency; 2) type of goal which is related to curbing discretion abuse; 3) object of control - state activities; 4) means of implementation - public policy; 5) civil ethics, based on non-violent methods. This system is not merely theoretical, it is based upon the interpretation of expert interviews of the leaders of the recognized non-governmental organizations. The author introduces the ideas on the five phases of institutionalization of public control, as well as the ideas of scenarios and types of institutionalization. 
DOI: $10.7256 / 1811-9018.2014 .6 .12206$

При цитировании этой статьи сноска на доі обязательна

\section{Право и политика $6(174) \cdot 2014$}

According to the offered methodology, the author analyzes three forms of organization of public control: representative of the public in the qualification boards of judges, public supervision commission and civil control over the police activities. Ключевые слова: институт, общественный контроль, суд, тюрьма, полиция, институционализаиия, актор, сиенарий, тип, общественно-наблюдательная комиссия.

Keywords: institution, public control, court, prison, police, institutionalization, actor, scenario, type, public supervision commission.

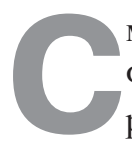

момента своего образования Российская Федерация прошла значительный путь от разрозненных инициатив к институциональному порядку осуществления общественного контроля в системах правосудия и правоохранительной деятельности. В отличие от стран с «естественно» сложившимися демократическими порядками, в России за короткий исторический период приходится осуществлять институционализацию общественного контроля одновременно (а не последовательно) с освоением различных практик общественного контроля ${ }^{1}$.

Вместе с тем, принятие и осуществление политикоуправленческих решений для институционализации общественного контроля несет на себе «родовые пятна» прежнего советского уклада, которые выражаются в создании подконтрольной псевдо-общественности, находящейся в различных аффилированных связях с представителями государственной власти.

Другим «родовым пятном» являются статистические данные, которые проходя сквозь правоохранительную систему как бюрократическую организацию, перестают быть источником знания о преступности, а становятся способом оценки работы самих ведомств и их сотрудников. Требования к отчетности формируют у правоохранителей практики работы со статистикой, существенно снижающие достоверность статданных о состоянии преступности в России ${ }^{2}$. Таким образом, лица принимающие решения и в целом общество, с одной стороны, не имеют достоверных данных, с другой стороны, оплачивается производство фиктивных цифр.

Несмотря на неблагоприятные условия развития для углубления демократизации, укрепления институтов гражданского общества в России в период 2011-2014 гг. следует проанализировать практики

\footnotetext{
${ }^{1}$ Под институционализацией понимается такая система, в которой осуществляется процесс обособления деятельности в отдельную сферу, что фиксируется во взаимной типизации среди других соответствующих институтов, а также задании системы мест в социальной действительности.

${ }^{2}$ Шклярук М.С. Правовая статистика: системный конфликт между знанием о преступности и учетом ведомственной работы. - СПб.: Институт проблем правоприменения при Европейском университете в Санкт-Петербурге, 2014.
}

общественного контроля в судебной системе и правоохранительной деятельности: представитель общественности в квалификационных коллегиях судей (ПО ККС), общественно-наблюдательные комиссии $(\mathrm{OHK)} \mathrm{и} \mathrm{гражданский} \mathrm{контроль} \mathrm{за} \mathrm{деятельностью}$ полиции (ГКДП).

Имплантация или прямое копирование учреждений, институтов, которые конституируют современные развитые общества от рынка и до публичной политики и прав человека, в истории новой России вновь переоткрыла проблему институционализации. В российских условиях мы имеем дело не со ставшими, а со становящимися институтами, причем, во многом, процесс институционализации носит искусственный, а не естественный характер, следовательно, подходы, как к созданию, так и к анализу данной проблематики должны быть другими.

Разновидности подходов к анализу проблемы институтов, которые предпринимаются в феноменологическом подходе ${ }^{3}$, не могут дать ответов на следующие вопросы:

1. Что должна представлять собой модель институционализации в условиях становления;

2. Каковы условия, при которых возможна институционализация форм организации общественного контроля;

3. Как в существующих условиях осуществлять институционализацию в системе правосудия и правоохранительной деятельности.

Для выработки нового подхода проведем предварительную концептуализацию проблемы.

\section{Концептуализация проблемы}

Для новой концептуализации проблемы необходимо разработать новый подход к анализу процесса институционализации форм общественного контроля. Возможно продуктивным будет ввести представление о институционализации не как об одномоментном действии, а о процессе, который проходит ряд фаз.

\footnotetext{
${ }^{3}$ Шмерлина И. А. Понятие «социальный институт»: анализ исследовательских подходов // Социологический журнал. 2008. № 4. с. $53-69$.
} 
Прежде всего, признаем значимость веберовской критики, в которой «институт», «государство», «общество» считаются конструктами нашего мышления и этим понятиям не стоит придавать онтологический статус, а единственно реальным фактом общественной жизни является социальное действие. С этой целью обратимся к идее социального конструирования реальности, составной частью которой является институционализация. В этом контексте основные признаки институционализации были сформулированы Лукманом и Бергером:

1. Институционализация рассматривается в контексте конструирования социальной реальности.

2. Всякая человеческая деятельность подвергается хабитуализации (опривычиванию).

3. Институт это взаимная типизация.

4. Чем более поведение институционализировано, тем более предсказуемым, а значит, и контролируемым оно становится.

5. Если бы все было институционализировано, то это было бы кошмаром для общества.

Экономист Е.Г. Ясин утверждает, что «институты обычно не строятся по единому плану или замыслу. Они выращиваются, культивируются в течение ряда поколений» 5 . А «особенность переживаемого нами периода, прежде всего, состоит в том, что общепризнанное правило или норма, применяемая ко всем безлично и объективно, у нас пока является инновацией, зачастую скопированной и формально применяемой моделью, которая приживается обычно с большим трудом» ${ }^{6}$.

В работах западных авторов показывается, что именно безличные связи позволяют обеспечить развитие в порядках открытого доступа?

Какие бы совершенные политические и социальные институты ${ }^{8}$ не были созданы они всегда рано или

\footnotetext{
${ }^{4}$ Бергер П., Лукман Т. Социальное конструирование реальности. Трактат по социологии знания. - М.: "Медиум”, 1995.

${ }_{5}^{5}$ Ясин Е.Г. Сценарии для России на долгосрочную перспективу. Новый импульс через два десятилетия [Текст] : докл. к XIII Апр. Междунар. Науч. Конф. По проблемам развития экономики и общества, Москва, 3-5 апр. 2012г. / Е.Г. Ясин ; Нац. Исслед. Ун-т «Высшая школа экономики». - М.: Изд. Дом Высшей школы экономики, 2012. С. 67.

${ }^{6}$ Там же C. 68.

${ }^{7}$ Норт Д., Уоллис Д., Вайнгаст Б. - Насилие и социальные порядки. Концептуальные рамки для интерпретации письменной истории человечества. - М.: Издательство Института Гайдара, 2011.

${ }^{8}$ Социальные институты типизируют социальные отношения в интересах неограниченного круга лиц. Корпоративные институты типизируют отношения уже существующие в конкретном профессиональном сообществе для решения вопросов ограниченного
}

поздно становятся оковами для развития, поэтому суть человека в том, чтобы освоив социальные институты преодолеть («снять», как сказал бы Гегель) их, построив соответствующую времени и месту такую форму организации общественного контроля и шире гражданского участия, которая, по крайней мере, могла бы быть соразмерной государственным формам организации. Описанная установка позволяет по-другому сформулировать основную функцию политической науки: надо не столько описывать действительность, сколько помогать «делать историю» и оснащать развитие, а точнее управление развитием, в том числе через построение типологизаций. Следует обращать усилия, прежде всего, на определение таких наборов понятий, которые позволяют добиться успеха в практической ситуации. Построение понятия институционализации должно быть дополнено рассмотрением методов институционализации и институциональным мышлением. Причем все это должно рассматриваться в историческом подходе. Рассмотрение методов институционализации и институционального мышления требует отдельного корпуса исследований и не является предметом обсуждения в настоящей статье.

В России и в настоящее время преобладает реализация традиционалистского (постсоветского) типа политических отношений, которые требуют человека дополитического 9 - отчужденного от государства, передавшего ему все свои полномочия. В этом случае политическая власть для человека является сакральной, востребующей харизматических и авторитарных лидеров $^{10}$, а также монополизации публичного пространства.

Данный тип отношений может быть охарактеризован через иерархичность и сфокусированность на уже свершившихся событиях, на ставшем.

Не отменяя традиционалистский тип, как бы поверх него, накладывается процесс формирования современного типа (сетевая форма организации политического), который имеет дело со становящимся, сосредотачивается на открывающихся возможностях и предполагает наличие человека политического, относящегося к государству как сложной и подотчетной системе сервисов. Особое внимание здесь уделяется законности

круга лиц. В демократических странах преобладает смешанные государственно-общественные, общественно-государственные и гражданские формы организации институтов.

9 Яковенко И.Г. Политическая субъектность масс. Культурологический аспект политической жизни в России - М.: Новый хронограф, 2009.

${ }^{10}$ Авшалумова Р., Кравченко И. Российских игреков среда заела // Ведомости, 22.05.14. №90 (3594). 


\section{Право и политика $6(174) \cdot 2014$}

и прозрачности процедур политико-управленческих решений, а понятие собственности распространяется, прежде всего, на зону ближайшего развития - будущее человека и его близкого круга. Человек в этом типе осознает себя как проект (программу), которым он может и хочет управлять, также культивируется уважение к человеческому достоинству и стремление к приватизации публичного поля, оставляя государству роль разумного регулятора общих правил игры.

Ситуация глубокой дисфункции существующего политического режима породила массовую политическую субъективацию непартийного типа, что поначалу застало бюрократию врасплох. Функционально процесс политической субъективации естественным путем приводит, как правило, к появлению таких субъектов как политические партии и движения, которые ставят своей целью приход к власти, что требует в разной степени вождистских идеологий, харизматических лидеров. Однако, в новых условиях гражданского протеста (2011-2014 гг.), по видимому, оформляется тенденция влиять на политическую власть, не беря ее ${ }^{11}$ и внимание уделяется контролю за процедурами, в частности за честными выборами. На арене неожиданно появился новый коллективный политический субъект, который может быть опознан, как гражданский стейкхолдер, желающий распоряжаться своим будущим, и обладающий как ресурсами новых информационных технологий, так и организацией действительно массовых акций протеста, в то время как представители ни одной из политических партий (даже проправительственных) такими ресурсами в достаточной мере не обеспечены. Обратим внимание, что массовые митинги в начале 2012-2013гг. собирались уже не под эгидой политических партий, а по инициативе гражданских групп ${ }^{12}$.

Стейкхолдер - это заинтересованный участник (группа влияния) процесса, держатель важного ресурса, оказывающий существенное влияние на деятельность, в данном случае, осуществляет гражданское влияние на принятие и реализацию политико-управленческих решений. Если позиция не имеет достаточного социального статуса, чтобы заявить о себе в качестве значимой и не может быть предъявлена так, чтобы ее не могли

\footnotetext{
${ }^{11}$ Holloway J. Change the World Without Taking Power: The Meaning of Revolution Today. - London: Pluto Press, 2002.

12 Зайцев Д.Г., Карастелев В.Е. Протестное движение в России 2011-2012 годов: проблема субъектности / Государство и общество в пространстве власти и политических коммуникаций. Политическая наука: Ежегодник 2013. / Российская ассоциация политической науки; гл. ред. А. И. Соловьев. М.: Российская политическая энциклопедия (РОССПЭН), 2013. С. 231-266.
}

не учитывать другие, то в существовании подобной позиции следует, как минимум сомневаться.

Что касается институционализации, то она должна помогать воспроизводить необходимые взаимно типизированные отношения, но человек должен иметь возможность (специально обучен!) ненасильственно преодолевать институты, которые сковывают развитие и выращивать новые формы организации. Кроме того институционализацию продуктивно рассматриват сквозь призму управления через знаковые системы ${ }^{13}$. Подобная интерпретация институционализации в современной реальности в России может быть эвристичной.

Рассмотрим далее три формы организации общественного контроля в судебной системе и правоохранительной деятельности.

\section{Методология}

С целью продуктивной аналитической работы, необходимо определить методологию исследования, которая может строиться на выделении единиц анализа общественного контроля. По мнению автора публикации, единица анализа это система, состоящая из пяти элементов: (1) акторы и их взаимодействие, основанное на взаимности социального действия, действующие на принципах самоуправления, самоорганизации, самодостаточности; (2) тип цели, который связан с ограничением произвола; (3) предмет контроля - государственная деятельность; (4) способ реализации - публичная политика; (5) гражданская этика, основанная на ненасильственных методах. Эта система взята не умозрительно, а после интерпретации экспертных интервью, полученных у лидеров ведущих общественных организаций ${ }^{14}$.

Другим элементом методологии является операция соотнесения, а не сравнения феноменов между собой, причем соотнесение должно выводить на эвристичную типологию. Т. е. в данном случае не сравниваются между собой три формы организации общественного контроля в правоохранительной деятельности и судебной системе (ОНК, ПО ККС и ГКДП). Вышеперечисленные формы соотносятся на двухуровневой шкале институционализации общественного контроля: по общей части - это вопросы рамок, целей, объектов, средств, результатов, а по специальной части, задающей спец-

\footnotetext{
${ }^{13}$ Щедровиикий Г.П. Идея деятельности и деятельностный подход / Г.П.Щедровицкий. - М.: РОССПЭН, 2010.

${ }^{14}$ Какабадзе Ш.Ш., Зайцев Д.Г., Звягина Н.А., Карастелев В.Е. Институт гражданского участия: проверка деятельностью субъектов // Полис. Политические исследования, 2011. № 3. С. 88-108.
} 
ифику применительно к теме настоящего исследования, - это вопросы типов и сценариев институционализации.

\section{Основания общественного контроля}

Общественный контроль за деятельностью государства - это жизненная необходимость для стабильного развития любой демократической страны, а опасность его устранения, как пишет известный социолог Зигмунд Бауман, становится причиной массового уничтожения людей ${ }^{15}$. Как верно подмечают аналитики «В отсутствие внешнего контроля любое ведомство склонно к безграничной экспансии, погоне за статистическими показателями, которые надуваются за счет незначительных и типовых, «валовых» дел, простых в преследовании нарушений» ${ }^{16}$.

Фундаментом для осуществления общественного контроля в России являются федеральные законы «Об Общественной палате Российской Федерации», «О порядке рассмотрений обращений граждан Российской Федерации», «Об общих принципах организации местного самоуправления в Российской Федерации», а также указы Президента РФ «О порядке образования общественных советов при федеральных министерствах, федеральных службах и федеральных агентствах, руководство деятельностью которых осуществляет Президент Российской Федерации, при федеральных службах и федеральных агентствах, подведомственных этим федеральным министерствам», «Об общественных советах при МВД РФ и его территориальных подразделениях». Нормы, закрепляющие механизмы общественного контроля содержатся и в ряде других федеральных законов: «О полиции», «О саморегулируемых организациях», «О рекламе», «Об адвокатской деятельности и адвокатуре в РФ».

\section{Анализ трех форм организации общественного контроля}

В судебной системе согласно Федерального закона от 14 марта 2002 г. N 30-Ф3 «Об органах судейского

\footnotetext{
${ }^{15} \mathrm{Cp}$. «холокост стал итогом уникального столкновения факторов, которые сами по себе были совершенно банальными и обычными; и что вину за такое столкновение в значительной степени следует возложить на освободившееся от общественного контроля политическое государство с его монополией на средства насилия и его дерзкой инженерией, завершивших демонтаж всех неполитических ресурсов власти и институтов общественного самоуправления» Бауман 3. Актуальность холокоста. - М.: Издательство «Европа», - 2012, С.14.

${ }^{16}$ Панеях Э. «Extra jus: Хорошее плохое ведомство». Ведомости,
} 16.05.2013. сообщества в Российской Федерации» существуют две формы общественного контроля - присяжные заседатели и ПО ККС.

Общественный контроль со стороны ОНК осуществляется на основании Федерального закона от 10.06.2008 г. № 76-Ф3 «Об общественном контроле за обеспечением прав человека в местах принудительного содержания и о содействии лицам, находящимся в местах принудительного содержания» (далее 76-ФЗ). Т.е. в сферу общественного контроля входят места лишения свободы, которые находятся в подчинении Федеральной службы исполнения наказаний, Министерства внутренних дел, Федеральной службы безопасности, Министерства обороны.

Кампании гражданского контроля за деятельностью полиции ${ }^{17}$, вне ОНК, осуществляется гражданами на основании общих положений законодательства, регулирующего работу полиции. Причем под функциями полиции понимается следующее: «предупреждение и расследование преступлений, поддержание общественного порядка и оказание помощи населению» ${ }^{18}$. Кроме того «у полиции есть и положительные обязательства, а именно - способствовать формированию среды, в которой люди могут пользоваться свободой и чувствовать себя в безопасности» ${ }^{19}$.

Эта мысль частично нашла свое воплощение в п.1, ст.1 закона РФ «О полиции»: «Полиция предназначена для защиты жизни, здоровья, прав и свобод граждан Российской Федерации, иностранных граждан, лиц без гражданства (далее также - граждане; лица), для противодействия преступности, охраны общественного порядка, собственности и для обеспечения общественной безопасности ${ }^{20}$.

Специфика рассматриваемых в настоящей работе форм общественного контроля состоит в том, что судебная система и правоохранительные органы по своей функции должны обеспечивать, в свою очередь, государственный контроль.

\footnotetext{
${ }^{17}$ Карастелев В. Общественный контроль за деятельностью полиции в России: возможности и реальные практики / Аналитический доклад о деятельности правозащитной сети. М. : Издательство «Юрист», 2013. С. 368-385.

${ }^{18}$ Ocсе A. Принципы деятельности полиции. - Амстердам: Amnesty International, 2006. C.50.

${ }^{19}$ Там же.

20 «О полиции» [электронный ресурс]: Федеральный закон от 07.02.2011 N 3-Ф3 (ред. от 03.02.2014). Доступ из справ. - правовой системы «Консультант Плюс».
} 


\section{Право и политика $6(174) \cdot 2014$}

Как пишет исследователь судебной системы И.Л. Петрухин «Во многих странах мира в разные времена суды осуществляли правосудие, но независимой судебной власти не было. Она появилась, когда суды освободились от диктата исполнительной и представительной властей и, более того, стали осуществлять за ними контроль. Этот процесс был связан с введением гарантий прав личности и обеспечением законности в судопроизводстве. Судебная власть, в частности, предназначалась для контроля за расследованием преступлений, где совершается немалое число нарушений закона... Конституция РФ 1993г. была прорывом в сторону демократии, свободы и гласности. Она учредила судебный контроль за другими ветвями власти и ввела этот контроль за соблюдением прав человека при расследовании преступлений (ст. 22-25)»²1.

Введение представителя общественности в ККС должно было изменить свойства ККС - сделать его прозрачным, доступным общественному контролю. Однако такого изменения не зафиксировано. Без института представителя общественности в ККС деятельность самого ККС не изменится, но это не значит, что от этого надо отказаться. Необходима последовательная, тонкая и системная реформация этого института в России. Особую проблему в реформации представляет сама судебная власть, которая, как показало исследование, не заинтересована в инкорпорировании элементов, могущих контролировать ее деятельность. Имея возможность влиять на персональный состав представителей общественности в ККС, органы законодательной власти (Совет Федерации, Законодательные собрания субъектов РФ) фактически не допускают тех, кто может оказаться нелояльным.

Напротив, у ФСИН и МВД гораздо меньше возможностей влиять на отбор кандидатов в члены ОНК, а на ГКДП им вообще очень трудно повлиять. Впрочем, это не мешает данным ведомствам проводить лояльных кандидатов в Общественные Советы при подразделениях полиции.

С точки зрения критерия соответствия - место для институционализации и ее наполнение должно соответствовать друг другу. В случае с институтом представителя общественности в ККС, как видно из исследования, этот место было заполнено лояльными

${ }^{21}$ Петрухин И.Л. Судебная власть: контроль за расследованием преступлений. - М.: ТК Велби, Изд-во Проспект, 2008. С.4. к судебной системе кандидатами ${ }^{22}$. В случае с ОНК это место до 2013 г. было заполнено в основном кандидатами, разделяющими правозащитные ценности, поэтому доверие и эффективность данной формы организации представляется более высокой. В случае мониторинга полиции со стороны гражданских организаций можно констатировать, что место и наполнение гораздо в большей степени соответствуют друг другу, но этот институт пока не является укорененным, хотя имеет сильную поддержку со стороны уже имеющегося законодательства и практики на международном уровне, особенно в ОБСЕ и Совете Европы.

В случаях с ОНК и ГКДП возникла еще не широкая, но уже самостоятельная социальная база, а в случае представителя общественности в ККС ее нет, что еще раз доказывает реализацию фиктивнодемонстративного сценария. Рост социальной самостоятельной базы также показывает доверие (или его отсутствие) общества к тому или иному явлению. Можно сделать вывод, что к институту представителя общественности в ККС доверия не наблюдается, а вот к деятельности ОНК и мониторинга полиции происходит его поступательный рост.

Гражданские активисты добились ношения жетонов с индивидуальными номерами полицейскими, находящимися на службе. Эта мера теперь носит охранительный характер и должна сдерживать произвол сотрудников полиции в отношении граждан. Эту же роль играет фото и видеосъемка полицейских, которую также можно свободно осуществлять. Все эти меры были приняты под давлением гражданских групп и организаций, заинтересованных в предохранительных целях. Теперь любая инициативная группа и отдельный гражданин может проверить легитимность несения службы полицейскими, имея перед собой технологизированную модель проверки, что начинает превращать разрозненные действия в массовый общественный контроль за деятельностью полиции.

Таким образом, гражданские инициативы вызвали появление новых свойств-функций в деятельности полиции, что служит доказательством эффективности данных мер и конструирует качество институциональности у этого вида деятельности, хотя о развитой институционализации речь еще не идет.

Анализ трех форм организации общественного контроля сведен в таблице 1 .

\footnotetext{
${ }^{22}$ Роль представителей общественности в повышении независимости и эффективности правосудия в Российской Федерации». М. : Московская Хельсинкская группа, 2011.
} 
DOI: $10.7256 / 1811-9018.2014 .6 .12206$

При цитировании этой статьи сноска на dоі обязательна

Власть и управление

Таблица 1. Сводная таблица форм организацчии общчественного контроля

\begin{tabular}{|c|c|c|c|c|}
\hline № & Критерий & ОНК & $\begin{array}{c}\text { Представитель обще- } \\
\text { ственности в ККС }\end{array}$ & $\begin{array}{c}\text { Общественный контроль } \\
\text { за полицией }\end{array}$ \\
\hline 1. & Рамки & $\begin{array}{l}\text { Соответствие деятельности } \\
\text { мест лишения свободы меж- } \\
\text { дународным стандартам, } \\
\text { Конституции и Федерально- } \\
\text { му законодательству. }\end{array}$ & $\begin{array}{l}\text { Соответствие деятельно- } \\
\text { сти ККС международным } \\
\text { стандартам, Конституции } \\
\text { и Федеральному законода- } \\
\text { тельству. }\end{array}$ & $\begin{array}{l}\text { Соответствие деятельности } \\
\text { полиции международным } \\
\text { стандартам, Конституции } \\
\text { и Федеральному законода- } \\
\text { тельству. }\end{array}$ \\
\hline 2. & Цели & $\begin{array}{l}\text { Улучшение практики об- } \\
\text { ращения с заключенными } \\
\text { на основе международных } \\
\text { стандартов. }\end{array}$ & $\begin{array}{l}\text { Обеспечение независимо- } \\
\text { сти и открытости для обще- } \\
\text { ственности ККС. }\end{array}$ & $\begin{array}{l}\text { Сделать из полиции сервис } \\
\text { для граждан, а не инструмент } \\
\text { контроля за населением. }\end{array}$ \\
\hline 3. & Объекты & Места лишения свободы. & Деятельность судей. & Деятельность полиции. \\
\hline 4. & Средства & $\begin{array}{l}\text { Посещения мест лишения } \\
\text { свободы. }\end{array}$ & Участие в заседаниях ККС. & $\begin{array}{l}\text { Мониторинг, кампании по } \\
\text { проверке документов, жето- } \\
\text { нов и посещения отделений } \\
\text { полиции. }\end{array}$ \\
\hline 5. & Результаты & $\begin{array}{l}\text { Вовлечение граждан, улуч- } \\
\text { шение ситуации в местах } \\
\text { лишения свободы. }\end{array}$ & Не известны. & $\begin{array}{l}\text { Изменение закона «О поли- } \\
\text { ции», изменение поведения } \\
\text { полицейских, привлечение } \\
\text { общественности при прове- } \\
\text { дении контроля. }\end{array}$ \\
\hline
\end{tabular}

\section{Сценарии институционализации}

Существуют, по крайней мере, два предельных типа государственного управления: первый - одностороннее планирование для абстрактных граждан (все определяется «государственным видением»); второй - подразумевает взаимность социального действия различных общественных групп, государства в создании социального порядка ${ }^{23}$.

Первый тип госуправления характерен для индустриального общества, а второй - для социального порядка, стоящего на ценностях модернизации. Россия, скорее всего, находится между этими двумя типами и вынуждена маневрировать, то приближаясь к модернизационному социальному порядку, то отталкиваясь от него.

В качестве своеобразных креплений, которые позволили бы России последовательно приближаться к модернизационной модели, могут служить различные

${ }^{23}$ Скотт Дж. Благими намерениями государства. Почему и как провалились проекты улучшения условий человеческой жизни: Пер. с англ. Э.Н. Гусинского, Ю.И. Турчаниновой. - М.: Университетская книга, 2005. С. 550. формы организации общественного контроля за ключевыми сферами государственной деятельности (суд, полиция, тюрьма).

Французские исследователи полагают, что: «Управлять сегодня означает опираться на такие способы действия, которые отличаются способностью принимать форму объективной необходимости, признаваемую группами ученых, чиновниками, сетями активистов. Перечислить эти модели действия, а еще лучше - проанализировать условия их применения - значит получить возможность понять, что сегодня «наука» дает публичной деятельности, и что эта деятельность дает «науке» ${ }^{24}$.

Предметом исследования не является институционализация сама по себе. Задача состоит в том, чтобы вскрыть те сценарии, по которым она разворачивается.

Общественный контроль возникает как яркое историческое явление в СССР в 1976г. в лице, например, Московской Хельсинкской группы, которая взялась следить за выполнением гуманитарных

${ }^{24}$ Новый общественно-политический словарь. Пер. с франц. Яз. - 


\section{Право и политика $6(174) \cdot 2014$}

статей Хельсинкского акта, принятого в 1975 г. в г.Хельсинки (Финляндия) ${ }^{25}$.

Общественный контроль важен даже не столько по своему продукту, хотя это тоже важно, но и по тому результату, который получается в результате предохранения от произвола, принятия непрозрачных решений.

На основе анализа применения различных моделей и проведенных коллективных исследований 26 можно предположить, что в России осуществляются три основных сценария институционализации общественного контроля за деятельностью правоохранительных органов и судебной системы.

Первый сценарий, по которому движется институт ПО ККС, носит фиктивно-демонстративный характер, не влияет на ситуацию в судебном сообществе, состав ККС не соответствует своему предназначению, общественность не знает о результатах деятельности своих «представителей». Кроме того, институционализации общественного контроля препятствует как само судейское сообщество, так и отсутствие технологизации процесса работы представителей общественности в ККС. В предложенной автором типологии это государственнообщественный тип (государство назначает граждан осуществлять деятельность по общественному контролю). Эта констатация отнюдь не означает, что надо отказаться от подобной формы общественного контроля, поскольку в случае изменения практики и корректировки закона данный институт может сыграть важную роль в обеспечении независимого и справедливого судопроизводства.

Второй сценарий, реализованный в мониторинге за деятельностью полиции, является сервисно-сетевым. Деятельность полиции понимается как сервис для граждан, а организационной основой являются гражданские и социальные сети. Здесь наиболее высоко соответствие между местом и наполнением, т.е. между функцией (независимый и качественный общественный контроль) и морфологией (гражданские качества проверяющих). В потенциале это может быть самой массовой и технологизированной формой организации общественного контроля в России. Пока же эти инициативы не носят массового характера, однако имеют тенденцию к расширению. Эта форма может быть типологизирована как гражданская (граждане, пользуясь соответствующим законодательством, сами берут на себя ответственность по осуществлению общественного контроля).

Третий сценарий, который реализуется в ОНК, может быть опознан, как рамочно-правовой и имеет наибольшее приближение к модели институционализации, в которой государственное управление учитывает взаимность социального действия. ОНК может быть отнесено к общественно-государственному типу (общественный орган - Общественная палата РФ, имеющая полномочия от государства, назначает и контролирует деятельность проверяющих граждан).

Сведем типологию акторов и сценариев в таблицу 2.

Таблицุа 2. Сводная таблиц̧а типологии акторов и сцеенариев организащчи общественного контроля

\begin{tabular}{|l|l|l|l|l|}
\hline \multicolumn{1}{|c|}{ № } & \multicolumn{1}{|c|}{ Критерий } & \multicolumn{1}{|c|}{ ОНК } & \multicolumn{1}{|c|}{$\begin{array}{l}\text { Представитель } \\
\text { общественности в КкС }\end{array}$} & $\begin{array}{l}\text { Гражданский контроль за } \\
\text { деятельностью полиции }\end{array}$ \\
\hline 1. & Тип актора & $\begin{array}{l}\text { Общественно-государствен- } \\
\text { ный }\end{array}$ & $\begin{array}{l}\text { Государственно-обществен- } \\
\text { ный }\end{array}$ & Гражданский \\
\hline 2. & Сценарии & Рамочно-правовой & $\begin{array}{l}\text { Фиктивно-демонстратив- } \\
\text { ный }\end{array}$ & Сервисно-сетевой \\
\hline
\end{tabular}

\footnotetext{
25 Родоначальником общественного контроля, который осуществлялся МХГ и другими правозащитными организациями, был Александр Есенин-Вольпин. Его идея заключалась в том, чтобы заставить советское государство выполнять законы. См. Алексеева Л. М. История инакомыслия в СССР. Новейший период. М.: «Весть», 1992. С.203.

${ }^{26}$ Роль представителей общественности в повышении независимости и эффективности правосудия в РФ. - М. : Московская Хельсинкская группа. - 2011.
}

\section{Фазы институционализации}

Для того чтобы проанализировать институционализацию в странах в процессе становления социальных институтов ее можно представить в виде пяти фаз: общественная потребность (1) - складывание практик 
(2) - инициативная группа по институционализации

(3) - легитимация ${ }^{27}(4)$ - легализация ${ }^{28}(5)$.

Используем данное представление по отношению к выделенным нами тремя формам общественного контроля, где каждая форма появляется в ответ на некоторые проблемы и противоречия. Так в ответ на закрытость судебного сообщества появляется инициатива ввести представителей общественности в ККС. А в ответ на многочисленные нарушения в местах принудительного содержания (СИЗО, ИВС, колонии) создать ОНК. ГКДП за деятельностью полиции был вызван произволом со стороны представителей МВД. Все три инициативы исходили из правозащитной среды, осуществлялись практически параллельно, однако привели к разным результатам.

Все три формы прошли первую фазу «общественная потребность», поскольку были заявлены неаффилированным с властями правозащитным сообществом.

Вторая фаза - «складывание практик» состоялась у ОНК и ГК, поскольку некоторые из используемых в настоящее время практик использовались еще во времена позднего советского периода. А вот сложить практики общественного контроля ПО ККС не удалось из-за закрытости и корпоративности судейского сообщества, реальной зависимости от властных структур, размытости в соответствующем федеральном законе понятия «представитель общественности». Если проанализировать открытые данные на сайте Высшей квалификационной коллегии судей (URL: http://vkks.ru/), то на май 2014 г. имеется информация о 261 представителе общественности. Так вот подавляющим большинством ПО ККС являются преподаватели вузов (42\%) и персонал бизнес-организаций (26\%). Судьи в отставке составляют - 7\%, пенсионеры МВД, прокуратуры, следствия - 8\%, госслужащие $-5 \%$, имеются также сотрудники аппарата политических партий («Единая Россия», КПРФ). Количество представителей общественных организаций не изменилось и составляет $2 \%$, т.е. всего представители четырех общественных организаций. Несмотря на то, что ПО ККС формально оказался в пятой фазе «легализация», тем не менее, нет оснований утверждать, что наличествует полноценная институционализация без прохождения второй-четвертой фаз.

\footnotetext{
${ }^{27}$ Под легитимацией понимаются способы объяснения и оправдания социальных и политических отношений, их когнитивная и нормативная интерпретация. Бергер П., Лукман Т. Социальное конструирование реальности. Трактат по социологии знания. - М.: «Медиум», 1995.

${ }^{28}$ Под легализацией понимается придание законной силы, официальное признание
}

ОНК - прошла все фазы институционализации, но переживает тенденцию размывания своего ядра за счет аффилированных с властями общественных организаций, которые по сути лишь имитируют реальные гражданские структуры ${ }^{29}$.

Проведенные исследования показывают, что в России сложился, правда, не достаточно массовый, сектор гражданских общественных организаций - $22 \%$ от всех общественных организаций ${ }^{30}$. Из данного типа организаций вполне можно рекрутировать людей для всех обозначенных выше форм организаций общественного контроля.

\section{Библиография:}

1. Holloway J. Change the World Without Taking Power: The Meaning of Revolution Today. - London: Pluto Press, 2002.

2. Авшалумова Р., Кравченко И. Российских игреков среда заела // Ведомости, 22.05.2014.

3. 3. Алексеева Л. М. История инакомыслия в СССР. Новейший период. М.: «Весть», 1992.

4. Бауман 3. Актуальность холокоста. - М.: Издательство «Европа»,-2012.

5. Беляева Н.Ю., Карастелев В.Е. Формы гражданского участия гражданских объединений в публичной политике // Сборник статей по итогам XII Международной научной конференции по проблемам развития экономики и общества Высшей школы экономики, 2012. С. 302-310.

6. Бергер П., Лукман Т. Социальное конструирование реальности. Трактат по социологии знания. - М.: "Медиум", 1995.

7. Зайцев Д.Г., Карастелев В.Е. Протестное движение в России 2011-2012 годов: проблема субъектности / Государство и общество в пространстве власти и политических коммуникаций. Политическая наука: Ежегодник 2013. / Российская ассоциация политической науки; гл. ред. А. И. Соловьев. М.: Российская политическая энциклопедия (РОССПЭН), 2013. С. 231-266.

${ }^{29}$ Петров Н. Субституты институтов // Золотой лев, 2007. №151152. URL: http://www.zlev.ru/151/151_31.htm. (дата обращения 19.05.2014).

${ }^{30}$ Беляева Н.Ю., Карастелев В.Е. Формы гражданского участия гражданских объединений в публичной политике // Сборник статей по итогам XII Международной научной конференции по проблемам развития экономики и общества Высшей школы экономики, 2012. C. $302-310$ 


\section{Право и политика $6(174) \cdot 2014$}

8. Какабадзе Ш.Ш., Зайцев Д.Г., Звягина Н.А., Карастелев В.Е. Институт гражданского участия: проверка деятельностью субъектов // Полис. Политические исследования, 2011. № 3. C. $88-108$.

9. Карастелев В. Общественный контроль за деятельностью полиции в России: возможности и реальные практики / Аналитический доклад о деятельности правозащитной сети. М. : Издательство «Юрист», 2013. С. 368-385.

10. Новый общественно-политический словарь. Пер. с франц. яз. - М.: Московская школа политических исследований, 2008.

11. Норт Д., Уоллис Д., Вайнгаст Б. Насилие и социальные порядки. Концептуальные рамки для интерпретации письменной истории человечества. - М.: Издательство Института Гайдара, 2011.

12. Оссе А. Принципы деятельности полиции. Амстердам: Amnesty International, 2006.

13. Панеях Э. Extra jus: Хорошее плохое ведомство // Ведомости, 16.05.2013.

14. Петров Н. Субституты институтов // Золотой лев, 2007. №151-152. Петрухин И.Л. Судебная власть: контроль за расследованием преступлений. - М.: ТК Велби, Изд-во Проспект, 2008.

15. Роль представителей общественности в повышении независимости и эффективности правосудия в Российской Федерации». М. : Московская Хельсинкская группа, 2011.

16. Скотт Дж. Благими намерениями государства. Почему и как провалились проекты улучшения условий человеческой жизни: Пер. с англ. Э.Н. Гусинского, Ю.И. Турчаниновой. - М.: Университетская книга, 2005.

17. Шклярук М.С. Правовая статистика: системный конфликт между знанием о преступности и учетом ведомственной работы. - СПб. : Институт проблем правоприменения при Европейском университете в Санкт-Петербурге, 2014.

18. Шмерлина И. А. Понятие «социальный институт»: анализ исследовательских подходов // Социологический журнал. 2008. № 4. с. 53 - 69.

19. Щедровицкий Г.П. Идея деятельности и деятельностный подход / Г.П. Щедровицкий. - М.: РОССПЭН, 2010.

20. Яковенко И.Г. Политическая субъектность масс. Культурологический аспект политической жизни в России. - М.: Новый хронограф, 2009.

21. Ясин Е.Г. Сценарии для России на долгосрочную перспективу. Новый импульс через два десятилетия [Текст] : докл. к XIII Апр. Междунар. Науч. Конф. По проблемам развития экономики и общества, Москва, 3-5 апр. 2012г. / Е.Г. Ясин ; Нац. Исслед. Ун-т «Высшая школа экономики». - М.: Изд. Дом Высшей школы экономики, 2012.

22. Соломатина Е.А. Правовое регулирование деятельности полиции в зарубежных странах // NB: Российское полицейское право. - 2013. - 3. - С. 104118. DOI: 10.7256/2306-4218.2013.3.8916. URL: http:// www.e-notabene.ru/pm/article_8916.html

23. Куракин А.В., Костенников М.В. Принципы организации и деятельности российской полиции // NB: Российское полицейское право. - 2013. - 2. - С. 2249. DOI: 10.7256/2306-4218.2013.2.799. URL: http:// www.e-notabene.ru/pm/article_799.html

24. Горелова О.А.. Проблемы привлечения судей к дисциплинарной ответственности в современном законодательстве и практике квалификационных коллегий судей // Политика и Общество. - 2014. - № 2. - C. 104-107. DOI: 10.7256/18128696.2014.2.1117

25. Волох В.А. Практика работы институтов гражданского общества в сфере миграции населения // NB: Проблемы общества и политики. -2013.-6. - C. 105-136. DOI: 10.7256/2306-0158.2013.6.598. URL: http://www.e-notabene.ru/pr/article_598.html

26. Н. Р. Исправникова, Д. Н. Романов Перспективы модернизации базовых институтов социальной сферы // Политика и Общество. - 2011. - 8. - С. 77-85.

27. Босхамджиева Н.А., Кашкина Е.В. Административно-правовое регулирование взаимодействия органов внутренних дел с институтами гражданского общества в сфере предупреждения правонарушений // Административное и муниципальное право. - 2010. - 9. - С. 13-17

28. Трегубова Е.В. Административные запреты в сфере осуществления полицейской деятельности // NB: Российское полицейское право. - 2013. - 1. - С. 25 -44. DOI: 10.7256/2306-4218.2013.1.718. URL: http:// www.e-notabene.ru/pm/article_718.html

29. Н. Р. Исправникова, Д. Н. Романов Перспективы модернизации базовых институтов социальной сферы // Политика и Общество. - 2011. - 8. - С. 77 - 85.

30. Айрих В.А. Соотношение общественной безопасности и превенции в полицейском праве ФРГ // NB: Национальная безопасность. 2013. - 1. - C. 254 - 289. DOI: 10.7256/23060417.2013.1.312. URL: http://www.e-notabene.ru/ $\mathrm{nb} /$ article_312.html 


\section{References (transliteration):}

1. Holloway J. Change the World Without Taking Power: The Meaning of Revolution Today. - London: Pluto Press, 2002.

2. Avshalumova R., Kravchenko I. Rossiiskikh igrekov sreda zaela // Vedomosti, 22.05.2014.

3. Alekseeva L. M. Istoriya inakomysliya v SSSR. Noveishii period. M.: «Vest'», 1992.

4. Bauman Z. Aktual'nost' kholokosta. - M.: Izdatel'stvo «Evropa»,-2012.

5. Belyaeva N.Yu., Karastelev V.E. Formy grazhdanskogo uchastiya grazhdanskikh ob'edinenii v publichnoi politike // Sbornik statei po itogam XII Mezhdunarodnoi nauchnoi konferentsii po problemam razvitiya ekonomiki i obshchestva Vysshei shkoly ekonomiki, 2012. C. 302-310.

6. Berger P., Lukman T. Sotsial'noe konstruirovanie real'nosti. Traktat po sotsiologii znaniya. - M.: "Medium", 1995.

7. Zaitsev D.G., Karastelev V.E. Protestnoe dvizhenie v Rossii 2011-2012 godov: problema sub'"ektnosti / Gosudarstvo i obshchestvo v prostranstve vlasti i politicheskikh kommunikatsii. Politicheskaya nauka: Ezhegodnik 2013. / Rossiiskaya assotsiatsiya politicheskoi nauki; gl. red. A. I. Solov'ev. M.: Rossiiskaya politicheskaya entsiklopediya (ROSSPEN), 2013. S. 231-266.

8. Kakabadze Sh.Sh., Zaitsev D.G., Zvyagina N.A., Karastelev V.E. Institut grazhdanskogo uchastiya: proverka deyatel'nost'yu sub' 'ektov // Polis. Politicheskie issledovaniya, 2011. № 3. C. 88-108.

9. Karastelev V. Obshchestvennyi kontrol' za deyatel'nost'yu politsii v Rossii: vozmozhnosti i real'nye praktiki / Analiticheskii doklad o deyatel'nosti pravozashchitnoi seti. M. : Izdatel'stvo «Yurist», 2013. C. 368-385.

10. Nort D., Uollis D., Vaingast B. Nasilie i sotsial'nye poryadki. Kontseptual'nye ramki dlya interpretatsii pis'mennoi istorii chelovechestva. - M.: Izdatel'stvo Instituta Gaidara, 2011.

11. Osse A. Printsipy deyatel'nosti politsii. - Amsterdam: Amnesty International, 2006.

12. Paneyakh E. Extra jus: Khoroshee plokhoe vedomstvo // Vedomosti, 16.05.2013.

13. Petrov N. Substituty institutov // Zolotoi lev, 2007. №151-152. Petrukhin I.L. Sudebnaya vlast': kontrol' za rassledovaniem prestuplenii. - M.: TK Velbi, Izd-vo Prospekt, 2008.

14. Skott Dzh. Blagimi namereniyami gosudarstva. Pochemu i kak provalilis' proekty uluchsheniya uslovii chelovecheskoi zhizni: Per. s angl. E.N. Gusinskogo, Yu.I. Turchaninovoi. - M.: Universitetskaya kniga, 2005.

15. Shklyaruk M.S. Pravovaya statistika: sistemnyi konflikt mezhdu znaniem o prestupnosti i uchetom vedomstvennoi raboty. - $\mathrm{SPb}$. : Institut problem pravoprimeneniya pri Evropeiskom universitete v SanktPeterburge, 2014.

16. Shmerlina I. A. Ponyatie «sotsial'nyi institut»: analiz issledovatel'skikh podkhodov // Sotsiologicheskii zhurnal. 2008. № 4. s. 53 - 69.

17. Shchedrovitskii G.P. Ideya deyatel'nosti i deyatel'nostnyi podkhod / G.P.Shchedrovitskii. - M.: ROSSPEN, 2010.

18. Yakovenko I.G. Politicheskaya sub' 'ektnost' mass. Kul'turologicheskii aspekt politicheskoi zhizni v Rossii. - M.: Novyi khronograf, 2009.

19. Yasin E.G. Stsenarii dlya Rossii na dolgosrochnuyu perspektivu. Novyi impul's cherez dva desyatiletiya [Tekst] : dokl. k XIII Apr. Mezhdunar. Nauch. Konf. Po problemam razvitiya ekonomiki i obshchestva, Moskva, 3-5 apr. 2012g. / E.G. Yasin ; Nats. Issled. Un-t «Vysshaya shkola ekonomiki». - M.: Izd. Dom Vysshei shkoly ekonomiki, 2012.

20. Solomatina E.A. Pravovoe regulirovanie deyatel'nosti politsii v zarubezhnykh stranakh // NB: Rossiiskoe politseiskoe pravo. - 2013. - 3. - C. 104-118. DOI: 10.7256/2306-4218.2013.3.8916. URL: http:/www.enotabene.ru/pm/article_8916.html

21. Kurakin A.V., Kostennikov M.V. Printsipy organizatsii i deyatel'nosti rossiiskoi politsii // NB: Rossiiskoe politseiskoe pravo. - 2013. - 2. - C. 22-49. DOI: 10.7256/2306-4218.2013.2.799. URL: http:/www.enotabene.ru/pm/article_799.html

22. Gorelova O.A.. Problemy privlecheniya sudei $\mathrm{k}$ distsiplinarnoi otvetstvennosti $\mathrm{v}$ sovremennom zakonodatel'stve i praktike kvalifikatsionnykh kollegii sudei // Politika i Obshchestvo. - 2014. - № 2. - S. 104-107. DOI: 10.7256/18128696.2014.2.1117

23. Volokh V.A. Praktika raboty institutov grazhdanskogo obshchestva v sfere migratsii naseleniya // NB: Problemy obshchestva i politiki. - 2013. - 6. - C. 105136. DOI: 10.7256/2306-0158.2013.6.598. URL: http:// www.e-notabene.ru/pr/article 598.html

24. N. R. Ispravnikova, D. N. Romanov Perspektivy modernizatsii bazovykh institutov sotsial'noi sfery // Politika i Obshchestvo. - 2011. - 8. - C. 77-85.

25. Boskhamdzhieva N.A., Kashkina E.V. Administrativnopravovoe regulirovanie vzaimodeistviya organov vnutrennikh del s institutami grazhdanskogo ob- 
DOI: $10.7256 / 1811-9018.2014 .6 .12206$

При цитировании этой статьи сноска на доі обязательна

\section{Право и политика $6(174) \cdot 2014$}

shchestva $\mathrm{v}$ sfere preduprezhdeniya pravonarushenii // Administrativnoe i munitsipal'noe pravo. - 2010. - 9. - C. 13-17

26. Tregubova E.V. Administrativnye zaprety v sfere osushchestvleniya politseiskoi deyatel'nosti // NB: Rossiiskoe politseiskoe pravo. - 2013. - 1. - C. 25 44. DOI: 10.7256/2306-4218.2013.1.718. URL: http:// www.e-notabene.ru/pm/article 718.html
27. N. R. Ispravnikova, D. N. Romanov Perspektivy modernizatsii bazovykh institutov sotsial'noi sfery // Politika i Obshchestvo. - 2011. - 8. - C. 77 - 85.

28. Airikh V.A. Sootnoshenie obshchestvennoi bezopasnosti i preventsii v politseiskom prave FRG // NB: Natsional'naya bezopasnost'. - 2013. - 1. - C. 254 289. DOI: 10.7256/2306-0417.2013.1.312. URL: http:// www.e-notabene.ru/nb/article_312.html 